pp. 7-14

\author{
Anna SZKOLAK-STĘPIEŃ \\ ORCID0000-0001-5957-5616 \\ Uniwersytet Pedagogiczny im. KEN w Krakowi e
}

Katarzyna ZIĘBA

ORCID 0000-0003-0187-4167

Uniwersytet Pedagogiczny im. KEN w Krakowie

\title{
Edukacja zdalna oczami dwóch pokoleń nauczycieli wczesnej edukacji
}

\begin{abstract}
Remote Education through the Eyes of Two Generations of Early Childhood Education Teachers

The aim of the article is to examine the views of early childhood education teachers about the realities of widely understood remote education. Due to the times of the pandemic, the research sample and the research itself is just a conversation with two teachers of early childhood education, taking into account the same research problems. The authors wanted them to be people who teach at the same level of education, with different professional experience and a diverse range of experiences. Both teachers were positive about the conversations. They were guided by the willingness to help and the curiosity of the research results.
\end{abstract}

Keywords: remote education, early childhood education, early childhood education teacher

Słowa kluczowe: edukacja zdalna, edukacja wczesnoszkolna, nauczyciel wczesnej edukacji

\section{Wprowadzenie}

Działania skupiające się na zapobieganiu, przeciwdziałaniu i zwalczaniu COVID-19 stały się współcześnie celem naszego życia i funkcjonowania. Koniecznością stało się uaktualnienie rozwiązań umożliwiających przedszkolom, szkołom i placówkom oświatowym działanie w zmienionych warunkach organizacyjnych, a także pracę $z$ wykorzystaniem metod i technik kształcenia na odległość. Odpowiedzialność za powodzenie procesów kształcenia w tej nowej rze-

www.czasopismoppiw.pl 
czywistości standardowo spoczęła na barkach nauczycieli. W przypadku najmłodszych dzieci ogromną rolę zaczęli odgrywać również rodzice.

$\mathrm{Z}$ powodu sytuacji epidemiologicznej Minister Edukacji Narodowej wydał 20 marca 2020 r. rozporządzenie, które reguluje zasady i sposoby funkcjonowania w rzeczywistości szkolnej (DzU, 2020, poz. 492). Ustawy dają także możliwość pewnych odstępstw i tam, gdzie to konieczne - realizacji zadań dydaktyczno-wychowawczych inaczej. Ma to być regulowane przez szkoły i placówki oświatowe w uzgodnieniu z organem prowadzącym. Finalnie celem tych wszystkich działań jest - mimo ograniczeń wynikających ze specyfiki współczesnego świata - nieprzerwana realizacja zasad podstawy programowej.

\section{Edukacja tradycyjna a edukacja zdalna}

W Encyklopedii pedagogicznej można przeczytać, że „kształcenie to całokształt takich poczynań, czynności, działań, procesów i metod oddziaływania jednostki i grupy, by efektem było wykształcenie ogólne tych jednostek i grup, czyli zdobycie kwalifikacji i kompetencji ogólnych" (Pomykało (red.), 1993, s. 296). Definicja odnosi się do procesu, którego głównym ogniwem jest relacja nauczycie1-uczeń zachodząca bezpośrednio. Wymaga ona podjęcia odpowiednich działań i zastosowania metod $\mathrm{w}$ celu osiągnięcia określonego celu i zdobycia nowych umiejętności/kwalifikacji. Współcześnie, w dobie pandemii, kształcenie odbywa się jednak w formie zdalnej. Jego cel w zasadzie jest podobny, wszystkie podejmowane aktywności mają rozwijać odbiorców, lecz definicje i poczynania podejmowane w tym procesie istotnie się różnią. Józef Półturzycki kształcenie zdalne określa jako:

[...] edukację prowadzoną przez pośrednictwo i pomoc poczty elektronicznej bez kontaktów bezpośredniej edukacji między nauczycielem a uczniem. Kształcenie to jest realizowane przez pisane lub drukowane i nagrane materiały przesyłane do ucznia, którego postępy są ustalone przez pisemne lub drukowane ćwiczenia przekazywane nauczycielom do kontroli i poprawy, a następnie zwracane uczniom z uwagami i oceną (1998, s. 302-303).

Zarówno edukacja tradycyjna, jak i edukacja zdalna mają swoich zwolenników i przeciwników. Nauczanie zdalne w szczególny sposób podkreśla wielką rolę nowych technologii we współczesnej edukacji. Nowe technologie to zarówno ogrom dodatkowych możliwości, jak i nowe wyzwania, które niejednokrotnie urastają do rangi problemów. Wymagają one bowiem zarówno od nauczycieli, jak i uczniów, oraz często też od ich opiekunów biegłej i sprawnej obsługi aplikacji, a także technicznej sprawności w użytkowaniu urządzeń (Korzan, 2021).

Według Wincentego Okonia nauczanie to „planowa i systematyczna praca nauczyciela z uczniami mająca na celu wywołanie pożądanych trwałych zmian 
w ich postępowaniu, dyspozycjach i całej osobowości — pod wpływem uczenia się i opanowywania wiedzy, przeżywania wartości i działań praktycznych" (1987, s. 194). Nauczyciele i uczniowie spotykają się w przystosowanych do tego salach dydaktycznych. Na zajęciach nauczyciel, posługując się różnymi metodami i technikami, odkrywa wraz z uczniami temat lekcji. Prowadzi zajęcia, koordynuje i aktywizuje uczniów do własnych działań i samodzielnego konstruowania wiedzy. Uczniowie pracują indywidualnie, w parach bądź w większych grupach. Zajęcia odbywają się w ławkach lub na dywanie, umieszczonym najczęściej z tyłu sali. Wykorzystanie nowoczesnych technologii jest $\mathrm{w}$ tym procesie mile widziane, ale stanowi pewnego rodzaju urozmaicenie/uzupełnienie, nie jest warunkiem koniecznym. Działania odbywają się w relacji bezpośredniej, polegają na pytaniach i odpowiedziach, na pracy i zabawie. Ważna jest nauczycielska obserwacja, która pozwala na ocenę zaangażowania oraz zrozumienia uczniów, dzięki czemu nauczyciel może niemal natychmiastowo reagować i korygować niezrozumiałe treści.

W przypadku nauczania zdalnego uczeń, jego rówieśnicy ani nauczyciele się nie spotykają. Dzieli ich ekran komputera, telefonu czy tabletu, cel tych spotkań jest jednak ten sam - nauka, edukacja, zdobywanie wiedzy, realizacja podstawy programowej. W edukacji zdalnej istnieje kilka rodzajów generacji kształcenia na odległość: dwie generacje kształcenia synchronicznego i dwie asynchronicznego - wspieranego najnowszymi technologiami bądź wręcz na nich bazującego. Są to:

- Generacja pierwsza, którą stanowi model korespondencyjny w tradycyjnym rozumieniu. Charakterystyczne dla tego modelu, oprócz korespondencji, są skrypty i podręczniki, materiały drukowane oraz lekcje nadawane przez radio.

- Drugą generację stanowi model multimedialny, w którym zasadniczymi nośnikami danych są lekcje zapisane na taśmach audio lub wideo, komputerowe dyskietki z oprogramowaniem oraz interaktywne taśmy i dyski wideo.

- Trzecią generację stanowi właśnie synchroniczny model teleedukacyjny. Wymaga on od uczniów i nauczycieli pewnej dyscypliny czasowej, gdyż zakłada on naukę w różnych miejscach, ale w tym samym czasie. Bazuje on na audio-/tele- i wideokonferencjach oraz na lekcjach emitowanych przez rozgłośnie radiowe i stacje telewizyjne.

- Czwarta generacja to asynchroniczny model, który bazuje w szczególności na nowych technologiach, takich jak interaktywne multimedia (CD-ROM i DVD) oraz materiałach publikowanych w sieciach komputerowych (zwłaszcza w internecie). Jest to model, w którym komputer (wspomagany siecią) przejmuje podstawową rolę medium (Galwas i in., 2002).

Współcześnie można mówić już o piątej generacji, która przynosi pod tym względem rewolucję. Pozwala na naukę w dowolnym czasie i dowolnym miejscu. Nauczyciel i uczeń korzystają z internetu, laptopa/tabletu/smartfona i za- 
instalowanych aplikacji oraz platform edukacyjnych, takich jak np. Microsoft Teams czy Zoom.

Aktualny system edukacyjny opiera się na płynnej hybrydzie trzeciej i czwartej generacji. Nauczyciele i uczniowie według swoich planów zajęć spotykają się na lekcjach w aplikacjach umożliwiające prowadzenie e-lekcji. Niejednokrotnie materiały lekcyjne są też dokumentowane przez nauczycieli i wysyłane do uczniów za pomocą poczty elektronicznej. Do zarchiwizowanych materiałów dzieci mogą w razie potrzeby powrócić lub zwyczajnie odtworzyć je w dogodnym czasie. Zdalne lekcje zawierają również sporo elementów modelu korespondencyjnego, występującego w pierwszej generacji. Dzieje się tak, ponieważ wiele materiałów przepływa pomiędzy uczniem i nauczycielem z użyciem kont poczty elektronicznej. Są to zarówno materiały edukacyjne, jak i zadania oraz prace egzaminacyjno-testowe. Dlatego też można pokusić się o stwierdzenie, że pandemia wymusiła użycie wszelkich dostępnych możliwości, aby praca edukacyjna mogła być jak najbardziej efektywna zarówno dla ucznia, jak i dla nauczyciela.

\section{Podstawy metodologiczne badań własnych}

Celem badań własnych było porównanie opinii na temat całokształtu edukacji zdalnej dwóch pokoleń nauczycieli wczesnej edukacji. Próbowano uzyskać odpowiedź na pytanie, w jaki sposób realia nauki zdalnej odbiera młody nauczyciel, a w jaki sposób ten $z$ długim stażem pracy i doświadczeniem. Ponadto czy według nauczycieli wczesnej edukacji nauczanie zdalne jest zjawiskiem pozytywnym, czy też nie? Jak zmienił się warsztat nauczycielski w czasie pandemii? Jakie skutki przyniesie zdalne nauczanie zdaniem badanych nauczycielek? Do realizacji celów badań własnych zastosowano metodę sondażu diagnostycznego, technikę wywiadu, kwestionariusz wywiadu z nauczycielami wczesnej edukacji. Próba badawcza była niewielka; stanowiły ją dwie nauczycielki wczesnej edukacji. Obie udzieliły jednak obszernych, szczegółowych odpowiedzi. Osobista rozmowa pozwoliła zaobserwować również emocje badanych, mimikę twarzy, uwagi dodatkowe, które wzbogaciły wyniki badań.

\section{Edukacja zdalna w opinii nauczycieli wczesnej edukacji}

Nauczycielki biorące udział $\mathrm{w}$ badaniu pracują na etapie edukacji wczesnoszkolnej. Pierwsza z nich, pani Wiola, ma 50 lat i od 30 lat pracuje w zawodzie. Druga rozmówczyni, pani Katarzyna, skończyła 30 lat i spełnia się w zawodzie od lat sześciu. 
W pierwszym etapie rozmowy zapytano nauczycielki, czy w ich opinii edukacja zdalna jest zjawiskiem pozytywnym, czy też negatywnym. Pani Wiola stwierdziła jednoznacznie, że „edukacja zdalna to porażka”. Podkreślała, iż „nikt nie raczył w żaden sposób przygotować do takiej zmiany ani nauczycieli, ani uczniów". Wspomniała o różnych możliwościach finansowych i technologicznych rodzin. Podkreślała deficyt kontaktów z rówieśnikami, który na dłuższą metę źle wpływa na uczniowską psychikę. Nie pominęła także aspektu oszustwa, czyli tego, że niejednokrotnie rodzice wyręczają dzieci w zadaniach czy odpowiedziach. Uczniowie lekceważą rangę zajęć, opuszczają spotkania (wychodzą do toalety, po napoje, żywność) bez pozwolenia, wracają i proszą o powtórzenie zadania lub informacji, co bardzo utrudnia pracę. Odpowiedź pani Katarzyny była bliźniaczo podobna. Poruszała ona te same kwestie, całą wypowiedź spuentowała jednak dość zaskakująco: „Według mnie edukacja zdalna nie jest zjawiskiem pozytywnym, jednak zdaję sobie sprawę z tego, że są osoby, którym ta forma nauki odpowiada, i to bardzo mnie martwi”.

Gdy dopytano panią Wiolę o plusy i minusy edukacji zdalnej, podkreśliła w swojej wypowiedzi istotę dostępności prezentacji i filmików, które można dzieciom pokazać i udostępnić w czasie zajęć: „U nas w szkole nie w każdej sali jest telewizor, teraz można dzieciom udostępnić ekran i lekcja staje się bardziej atrakcyjna, to jedyny plus" — dodała.

Pani Katarzyna, wymieniając pozytywne strony edukacji zdalnej, skupiła się na jej stronie organizacyjnej, mówiąc, że „pewne pozytywy chowają się w tym, że uczeń może pracować w swoim tempie, nie traci czasu na dojazdy do szkoły i rodzice mogą zaobserwować zaangażowanie (lub brak zaangażowania) dziecka na zajęciach".

Dalsza część rozmowy dotyczyła warsztatu metodycznego współczesnego nauczyciela wczesnej edukacji. Zapytano, jak on wygląda, prosząc o wskazanie narzędzi edukacji zdalnej, które są nieodzowne w pracy nauczyciela (strony internetowe, aplikacje, gry, platformy). Pani Wiola powiedziała tylko o aplikacji Microsoft Teams, za której pośrednictwem prowadzi wszystkie zajęcia, i serwisie YouTube, z którego również często korzysta, by odtworzyć piosenki lub filmiki pomocnicze. Pani Katarzyna natomiast wykorzystuje rozmaite aplikacje edukacyjne. $\mathrm{Na}$ zajęciach korzysta $\mathrm{z}$ aplikacji Kahoot i Quizlet, a ponadto Wordwall, Learning Apps, Cisco Webex Meetings, Quizziz.

Pani Katarzyna, zapytana o to, czy przeniesienie nauczania do sieci ułatwia pracę nauczyciela, czy miewa jakieś trudności związane $z$ aktualnym trybem pracy, przyznała, że „początki były dramatyczne. Samo przygotowanie do nauczania zdalnego wymusiło zdobycie zupełnie nowych umiejętności cyfrowych, które wcześniej nie były wymagane. Ale w przyrodzie nic nie ginie i te umiejętności będą przydatne. Jednak dodatkowa praca zdecydowanie nie była ułatwieniem". Jeśli chodzi o trudności, przyznała, że miewa częste bóle głowy z po- 
wodu długiego czasu spędzanego przed ekranem. „Większy też jest poziom stresu $\mathrm{z}$ wiązany $\mathrm{z}$ chaosem informacyjnym. Ciężko nadążyć za zmieniającymi się zarządzeniami”.

Pani Wiola w tej samej kwestii powiedziała stanowczo: „Nie poprawia, wręcz przeciwnie!. Dużo czasu spędzam przy komputerze, na rozmowach telefonicznych z rodzicami. Każdą lekcję trzeba przeorganizować od początku. Mało czasu na wytłumaczenie tematu, nie ma czasu na pytanie uczniów, lekcja ma trwać nie 45 minut, a tylko 30”. Narzekała, że „największym problemem jest złośliwość rzeczy martwych, czyli problemy ze sprzętem i łączem internetowym". Na pytanie, jaki rodzaj kontaktu z uczniem woli, czy ten bezpośredni, czy w formie zdalnej, również bez wahania wskazała na pierwszy. Powołała się na brak wspólnych wycieczek czy też zajęć pozalekcyjnych, na których można poznać dzieci z innej strony, porozmawiać z nimi na różne tematy, pomóc im w rozwiązywaniu problemów.

Pani Katarzyna w odpowiedzi na to pytanie była bardziej ostrożna, mówiąc, że „w jednym i drugim sposobie kontaktu mam coś, co lubię lub nie, kontakt internetowy np. przez wiadomości na Librusie zawsze zostawia po sobie ślad. W razie kontroli organu prowadzącego albo Kuratorium mogę przedstawić, jak układa się współpraca z rodzicem i uczniem oraz jak uczeń wywiązuje się z obowiązku szkolnego. Daje to pewien komfort psychiczny. Kontakt pośredni jest też dużo szybszy niż ten bezpośredni. Wiadomość można napisać niemal o każdej porze, natomiast wywiadówek czy konsultacji jest kilka w roku".

$\mathrm{Na}$ koniec poproszono obie panie o to, żeby spróbowały określić, jakie ich zdaniem będą w przyszłości skutki zdalnego nauczania. Pani Wiola powiedziała o obawie, że poziom wykształcenia uczniów będzie dużo niższy, ponieważ dzieci (w większości) nie pracują ani systematycznie, ani samodzielnie — „odpisują zadania z Internetu, klasówki piszą wspólnie na telefonach”. Pani Katarzyna przewiduje natomiast możliwość wystąpienia u dzieci wad postawy, stanów depresyjnych i uzależnienia się od internetu. Jest jednak większą optymistką. W przeciwieństwie do pani Wioli (która pozytywnych aspektów zdalnego nauczania absolutnie nie widzi) wyraża nadzieję, że obecna sytuacja może zwiększyć samodzielność uczniów. „Może, ale wcale nie musi” — dodaje na końcu.

\section{Wnioski}

Z uzyskanych odpowiedzi wynika jednoznacznie, że edukacja zdalna w opinii obu nauczycielek jest zjawiskiem negatywnie wpływającym na proces uczenia się i nauczania. Wady tej edukacji przewyższają jej zalety. Przede wszystkim zaciera się granica pomiędzy domem a szkołą. Uczeń zdobywa wiedzę w miejscu, 
które wcześniej kojarzyło mu się z odpoczynkiem i beztroską. Dzieci w wieku przedszkolnym i młodszym szkolnym mogą czuć się zagubione $\mathrm{w}$ takiej sytuacji. Nie mają ponadto bezpośredniego kontaktu z rówieśnikami oraz nauczycielem, który jest tak ważny $\mathrm{w}$ ich wieku, jest największym autorytetem. Nauka on-line zmusza ich do korzystania $\mathrm{z}$ urządzeń cyfrowych $\mathrm{w}$ większym natężeniu, niż to było wcześniej. Ma to negatywny wpływ na ich rozwój psychoruchowy. Nauczyciele mają problem z dokonaniem prawidłowej ewaluacji osiągnięć ucznia, gdyż czasem nie są w stanie ocenić, co było własnym wkładem pracy ucznia, a co rodzica. Kwestie organizacyjne dotyczące dojazdów do szkoły czy komfortu pracy w różnym tempie dla uczniów nie są na tyle przekonujące, aby je podnosić jako istotne zalety.

Nauczanie zdalne zmieniło całkowicie sposób prowadzenia zajęć. W krótkim czasie zarówno nauczyciele, jak i uczniowie musieli wpasować się w nowe realia. Na początku wszystkim sprawiało to trudność, lecz z czasem, metodą prób i błędów, udało się wypracować wspólny front. Samo przygotowanie do nauczania zdalnego wymusiło zdobycie zupełnie nowych umiejętności cyfrowych, które wcześniej nie były wymagane, np. prowadzenie zajęć za pośrednictwem platform typu Zoom czy Webex. To z pewnością jest plus. Po powrocie do nauczania tradycyjnego wiele tych nowo zdobytych umiejętności będzie wykorzystywanych przez nauczycieli do urozmaicania zajęć oraz ułatwiania pracy sobie i uczniom. Obecnie jednak zdalna forma nauczania jest raczej utrudnieniem niż ułatwieniem. W warsztacie metodycznym i dydaktycznym nauczyciela zmieniło się absolutnie wszystko. Kredę zastąpiły myszki i klawiatury. Tablicę — laptopy i tablety. Wywiadówki i zajęcia szkolne - e-spotkania. W opinii obu nauczycielek nie jest to zjawisko pozytywne.

\section{Zakończenie}

Podsumowując, można powiedzieć, że obie nauczycielki, bez względu na wiek, staż, poziom awansu i doświadczenie, najpierw wskazują na trudności związane $z$ edukacją zdalną, drastyczność jej skutków, niedociągnięcia. Boją się zagubienia w chaosie informacyjnym, drżą o odpowiednie przygotowanie swoich uczniów do nauki na wyższych etapach edukacyjnych, martwią się poziomem realizacji podstawy programowej. Przewagą młodszego pokolenia nauczycielskiego jest w dzisiejszych czasach większa swoboda i płynność w obsłudze nowych technologii. Naprawdę duży warsztat wirtualnych narzędzi, perfekcyjnie obsługiwany, pozwala utrzymać wysoki standard zajęć. Nauczyciele doświadczeni za to dominują w kwestii spokoju i opanowania. Dzięki temu mają większą łatwość utrzymania porządku (nawet podczas tych wyjątkowych zajęć). Jest to dla nich również wyzwanie (nauka nowych umiejętności), co zamienia się w do- 
datkową dawkę motywacji. Obie badane nie mogą się jednak doczekać powrotu do szkoły. Zdaniem autorek — większa część uczniów także.

\section{Bibliografia}

Galwas, B., Nowak, J., Nowak, S., Pajer, M., Witoński, P. (2002). Edukacja w Internecie. „MEWa”, nr 1 , s. 12-22.

Korzan, D. (2021). Ewolucja kształcenia zdalnego, http://www.korzan.edu.pl/pdf/zdalne.pdf (dostęp 19 IV 2021).

Okoń, W. (1987). Słownik pedagogiczny. Wyd. 4. Warszawa: PWN.

Pomykało, W. (red.) (1993). Encyklopedia pedagogiczna. Warszawa: Fundacja Innowacja.

Półturzycki, J. (1998). Edukacja dorostych za granica. Toruń: Wyd. Adam Marszałek.

Rozporządzenie Ministra Edukacji Narodowej z dnia 20 marca 2020 r. zmieniające rozporządzenie w sprawie czasowego ograniczenia funkcjonowania jednostek systemu oświaty w związku z zapobieganiem, przeciwdziałaniem i zwalczaniem COVID-19. DzU, 2020, poz. 492. 